\title{
TINJAUAN HIV-ASSOCIATED NEUROCOGNITIVE DISORDER (HAND) PADA PASIEN HIV TANPA INFEKSI OPORTUNISTIK
}

\author{
Gde Putra Dhyatmika, Ketut Widyastuti, Anak Agung Ayu Putri Laksmidewi
}

Departemen Neurologi, FK Universitas Udayana/RSUP Sanglah, Denpasar, Bali, Indonesia

Diterima 15 Juli 2019

Disetujui 10 Maret 2019

Publikasi 1 September 2019

Korespondensi: putra_dhytamika@gmail.com
Putra, et al. 2019. Tinjauan Hiv-Associated Neurocognitive Disorder (Hand) Pada Pasien Hiv Tanpa Infeksi Oportunistik. Callosum Neurology Journal 2(3): 119-127. DOI: https://doi.org/10.29342/cnj.v2i3.86

\begin{abstract}
ABSTRAK
Latar Belakang: Infeksi Human Immunodeficiency Virus (HIV) memiliki komplikasi sistem saraf pusat berupa gangguan fungsi kognitif HIV-associated neurocognitive disorder HAND). Replikasi HIV jangka panjang di astrosit dan mikroglia menurunkan fungsi neuronal. Kasus: Perempuan, 28 tahun, suku Bali, mengeluh mudah lupa selama dua tahun. Pasien beraktivitas harian secara mandiri. Pasien terkena infeksi HIV sejak September 2015, CD4 $16 \mathrm{sel} / \mu \mathrm{l}$ dan mendapat ARV fixed-dose combination dengan regimen tenofovir, lamivudine, dan efavirenz.
\end{abstract}

Diskusi: Pasien didiagnosis HAND Asymptomatic Neurocognitive Impairment (ANI). Kadar $\mathrm{CD}_{4}$ berhubungan dengan kerusakan neuron otak. Kadar $\mathrm{CD}_{4}$ nadir rendah ( $\leq 200 \mathrm{sel} / \mathrm{\mu l}$ ) merupakan risiko gangguan kognitif pada HIV. Terapi ARV meningkatkan performa fungsi kognitif dan fungsional. Si

pulan: Infeksi HIV pada SSP menyebabkan gangguan neurokognitif dan inisiasi ARV mencegah terjadinya perburukan.

Kata Kunci: HIV, gangguan kognitif, HAND, CD4, ARV

\footnotetext{
ABSTRACT

Background: Human Immunodeficiency Virus (HIV) infection complication in central nervous system (CNS) is HIV-associated neurocognitive disorder (HAND). Longterm HIV replication in CNS occurs in astrocytes and microglia and compromises neuronal function. Case: A 28 years old Balinese female has been forgetful for two years. She can carry out daily activities independently. She had HIV infection since September 2015 with CD4 of 16 cells $/ \mu$ and received fixed-dose combination ARV therapy with tenofovir, lamivudine, and efavirenz.
}

Discussion: This patient had HAND type Asymptomatic Neurocognitive Impairment(ANI). CD4 level is associated with brain tissue damage. Low nadir CD4 ( $\leq 200$ cells $/ \mu$ l) is risk factor for cognitive impairment in HIV. ARV improves cognitive function and performance. Conclusion: Direct HIV infection in CNS can cause neurocognitive disorders and ARV teraphy can prevent further worsening of the disease. Keywords: HIV, cognitive impairment, HAND, CD4, ARV 


\section{Latar Belakang}

Infeksi Human Immunodeficiency Virus (HIV) telah menjadi epidemi di seluruh dunia termasuk di Indonesia. Data dari Kementerian Kesehatan RI menunjukkan semakin bertambahnya kasus penderita HIV dari tahun ke tahun. Dari bulan Januari sampai Maret 2017 jumlah infeksi HIV yang dilaporkan sebanyak 10.376 orang dengan persentase yang tertinggi pada kelompok usia 25-49 tahun. ${ }^{1}$ Komplikasi neurologis akibat infeksi HIV dapat mengenai sistem saraf pusat (SSP) maupun sistem saraf tepi (SST). Komplikasi pada SSP dapat bermanifestasi sebagai demensia terkait HIV dengan gejala berupa gangguan kognitif, motorik, dan gangguan perilaku. Gangguan kognitif pada pasien dengan HIV dikenal sebagai HIV-associated neurocognitive disorder (HAND), memiliki gejala bervariasi dari yang secara klinis tidak bermanifestasi sampai demensia berat. ${ }^{2}$ Secara umum derajat HAND dapat dibagi menjadi HIV associated dementia (HAD), gejala yang lebih ringan disebut minor neurocognitive disorder (MND), dan pada kasus asimptomatik disebut dengan asymptomatic neurocognitive impairement (ANI). ${ }^{2}$ Perkembangan terapi HIV dengan antiretroviral kombinasi (ARV) telah menurunkan insiden gangguan kognitif dibandingkan era pra-ARV. Komplikasi gangguan kognitif ini dipengaruhi oleh ARV, adanya infeksi oportunistik, usia, merokok, tingkat pendidikan, serta dapat terjadi pada penderita HIV asimtomatik. $^{3}$ Gangguan kognitif merupakan salah satu gejala awal penurunan fungsional yang mencerminkan kerusakan neuron otak sehingga sangatlah penting untuk mengetahui fungsi kognitif pada pasien dengan HIV.

\section{Kasus}

Pasien perempuan, usia 28 tahun, suku Bali, kinan, kontrol ke poliklinik Neurobehavior RSUP Sanglah Denpasar. Pasien mengeluh mudah lupa yang dialami sejak sekitar dua tahun lalu. Pasien sering melupakan tempat dimana meletakkan barang-barang kecil seperti kunci dan dompet serta kesulitan untuk mengingat nama orang yang baru ditemuinya. Keluhan ini dirasakan makin lama makin bertambah berat hingga terkadang dirasakan mengganggu aktivitasnya. Aktivitas pasien sehari-hari pasien seperti makan, mandi, berpakaian, mengatur uang, dan menggunakan telepon masih dapat dilakukan dengan mandiri. Riwayat perubahan perilaku tidak dikeluhkan oleh keluarga pasien. Pasien seorang ibu rumah tangga, pendidikan terakhir sarjana, tidak merokok ataupun minum alkohol. Pasien memiliki riwayat infeksi HIV yang diketahui sejak bulan September 2015 dengan hasil pemeriksaan CD4 nadir $16 \mathrm{sel} / \mu \mathrm{l}$. Suami pasien dikatakan juga positif mengidap HIV. Pasien kontrol rutin tiap bulan ke poliklinik VCT RSUP Sanglah Denpasar dan mendapat terapi antiretroviral fixed dose combination dengan regimen tenofovir $300 \mathrm{mg}$, lamivudine $300 \mathrm{mg}$, efavirenz 600mg. Kadar $\mathrm{CD}_{4}$ current $209 \mathrm{sel} / \mu \mathrm{l}$ (bulan Januari 2018). Pasien juga memiliki riwayat kejang sejak bulan September 2015. Saat itu dikatakan pasien mengalami kejang saat sedang mengantri mengantar anak berobat dengan pola mata mendelik ke atas, keempat ekstremitas kaku lalu menghentak-hentak selama dua menit. Saat kejang pasien tidak sadar. Sebelum kejang pasien sadar baik. Setelah kejang pasien bingung lalu sadar baik. Kejang dikatakan muncul sebanyak tiga kali dalam waktu satu bulan. Pasien mendapat terapi fenitoin $2 \times 200 \mathrm{mg}$ dan asam folat $2 \times 400 \mathrm{mcg}$. Kejang dikatakan terkontrol dan terakhir pasien kejang dua tahun lalu dengan rutin minum obat. Saat pemeriksaan pasien sadar, kontak dan komunikasi baik. Pada pemeriksaan fisik didapatkan tanda vital dalam batas normal. Pemeriksaan klinis neurologis didapatkan GCS $\mathrm{E}_{4} \mathrm{~V}_{5} \mathrm{M}_{6}$ dengan riwayat bangkitan umum tonik klonik, tidak dijumpai adanya tanda regresi. Pemeriksaan neurobehavior dijumpai atensi baik, gangguan memori terutama new learning ability, memori tunda, dan asosiasi berpasangan, serta gangguan visuospasial dan eksekutif. ADL dan IADL mandiri. Hasil penapisan MMSE: 24, MoCA Ina: 14, Clock Drawing Test: 3, Trial making test $A$ baik, Trial making test $B$ terganggu, International HIV Dementia Scale (IHDS): 10.5, Skala penilaian depresi Hamilton: 15. Hasil CT Scan kepala dengan kontras didapatkan kesan tidak tampak adanya tandatanda perdarahan, infark, massa intraserebral maupun intraserebellar, edema serebri dan hidrosefalus. 


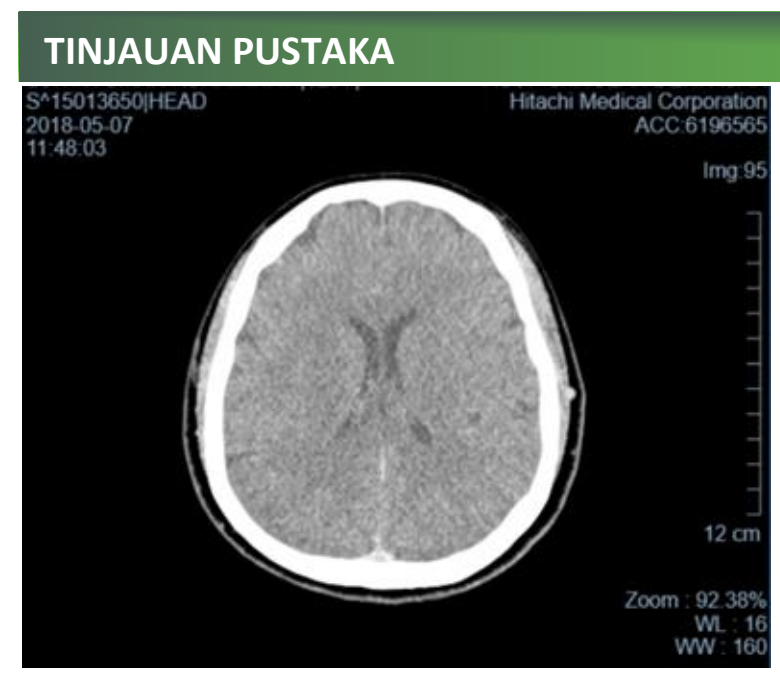

Gambar 1. CT Scan kepala tanpa dan dengan kontras dalam batas normal

Pasien didiagnosis dengan Asymptomatic Neuroconitive Impairment terkait Infeksi HIV (domain memori, kalkulasi, visuospasial, serta eksekutif) dan pasien direncanakan untuk dilakukan terapi stimulasi kognitif berupa latihan memori dan visuospasial menggunakan program komputer secara rutin seminggu sekali di polikinik Neurobehavior RSUP Sanglah Denpasar. Evaluasi ulang akan dilakukan tiap minggu untuk memantau perkembangan fungsi kognitif pasien.

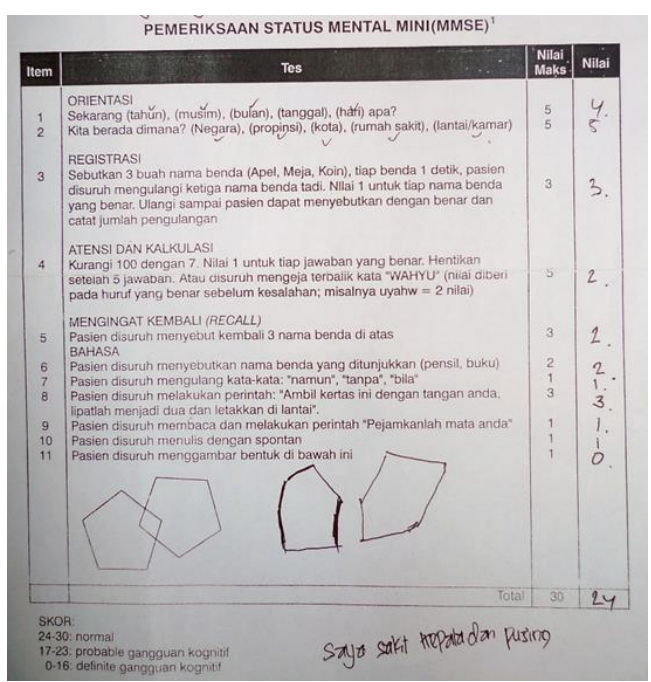

Gambar 2. Hasil pemeriksaan MMSE
Dhyatmika (et al) 2019

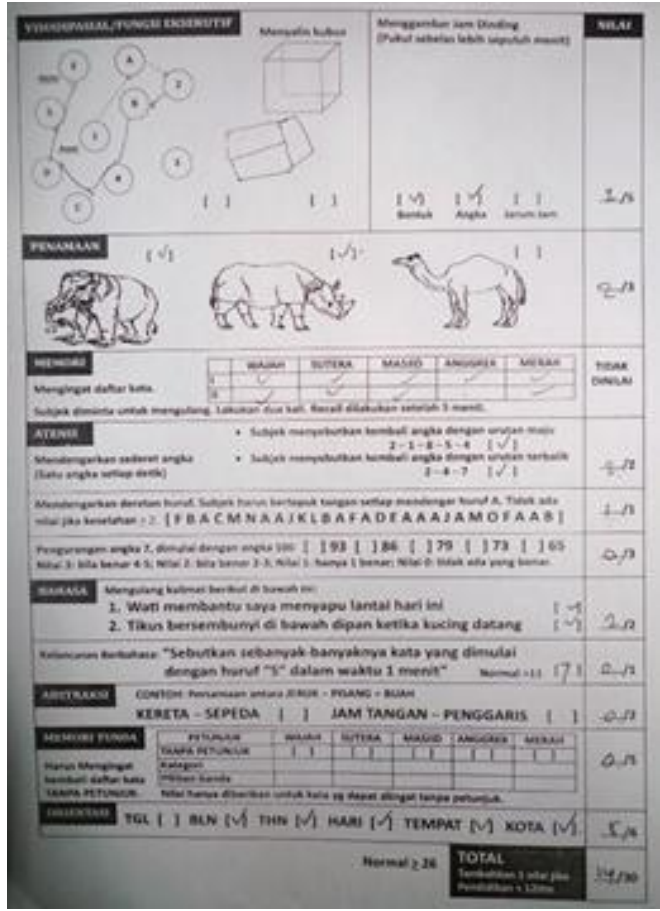

Gambar 3.Hasil pemeriksaan MoCA-Ina

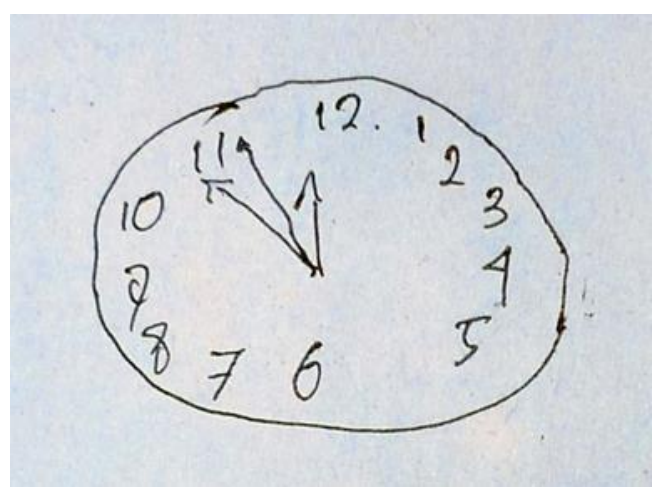

Gambar 4. Hasil pemeriksaan Clock Drawing Test

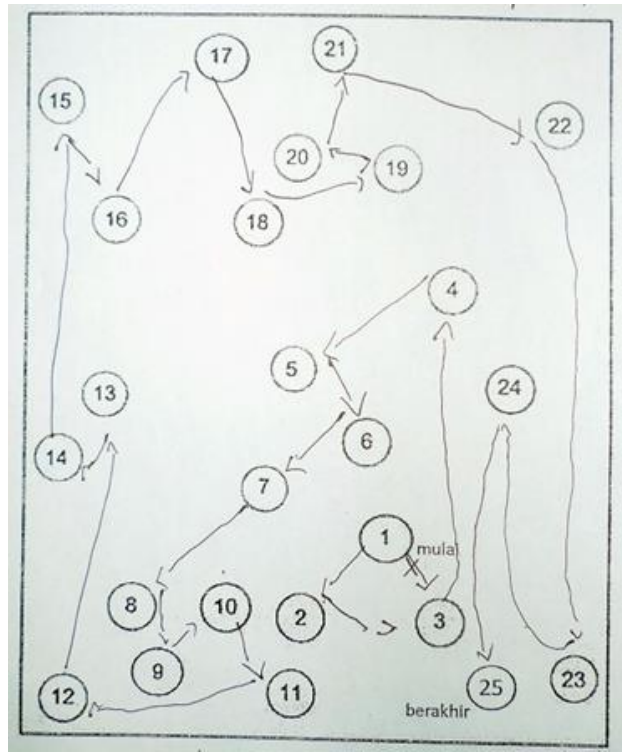

Gambar 5. Hasil pemeriksaan Trial making test $A$ 


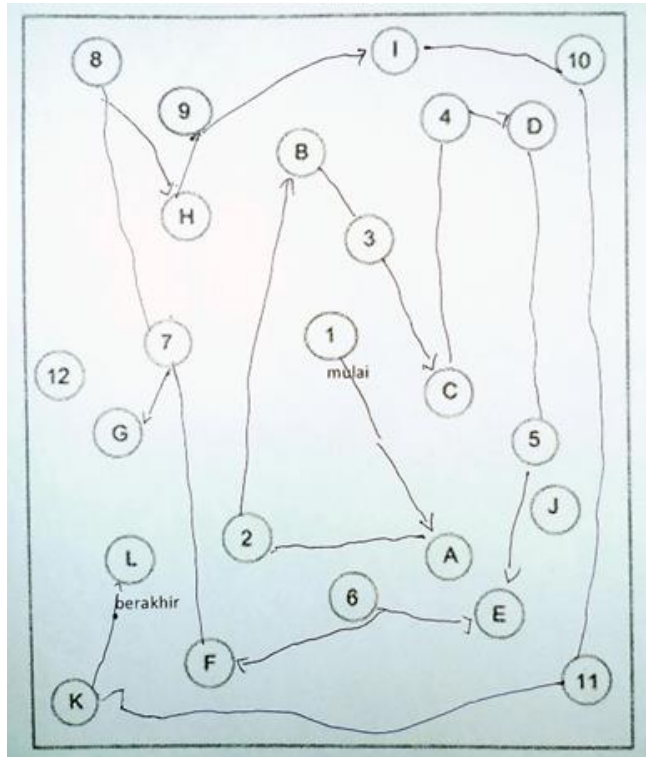

Gambar 6. Hasil pemeriksaan Trial making test $B$

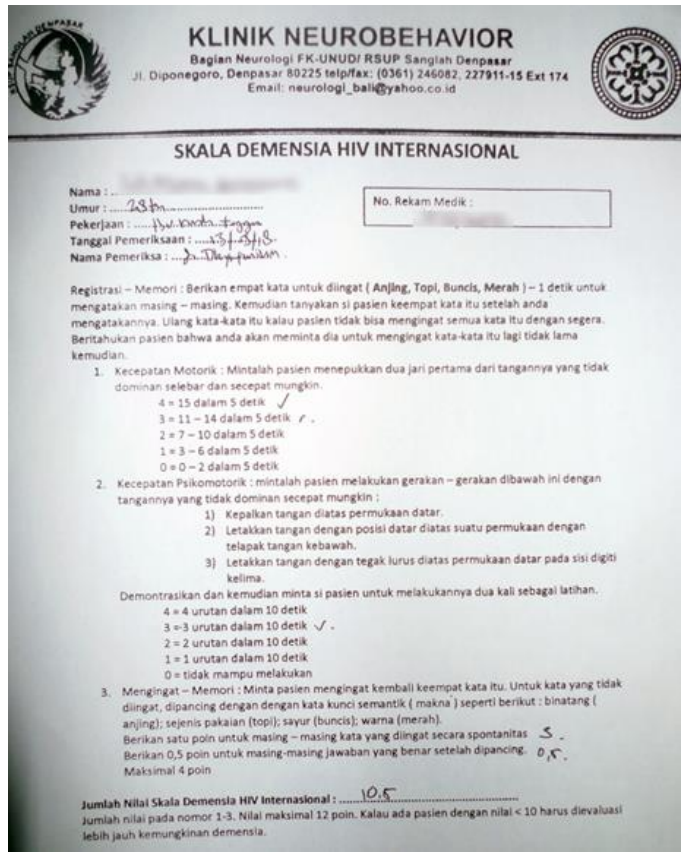

Gambar 7. Hasil pemeriksaan International HIV Dementia Scale (IHDS)

\section{Pembahasan}

Infeksi HIV berhubungan dengan terjadinya perubahan patologis pada SSP, terutama pada daerah subkortikal dan frontostriatal, termasuk ganglia basalis, substansia alba, dan hippokampus. HIV jarang secara langsung menyerang sel neuron. Infeksi HIV pada otak terjadi pada sel yang termasuk dalam lineage makrofag, termasuk makrofag perivaskular derivat monosit dan mikroglia. HIV menyerang otak melalui mekanisme Trojan Horse dengan menyeberang sawar darah otak menumpang monosit terinfeksi yang selanjutnya berdiferensiasi menjadi makrofag. Hal ini dapat terjadi dalam 1-2 minggu setelah virus masuk ke dalam sikulasi sistemik. Kerusakan neuron diperkirakan terjadi melalui dua mekanisme. Pertama melalui protein viral yang dilepaskan dari monosit terinfeksi menyebabkan kematian neuron melalui interaksi langsung protein viral dengan neuron. Kedua secara tidak langsung terjadi kematian neuron melalui mediasi oleh respon inflamasi terhadap protein viral maupun sel yang terinfeksi HIV tersebut. ${ }^{4}$

Salah satu komplikasi HIV berupa gangguan kognitif yang dikenal dengan istilah HIVassociated neurocognitive disorder (HAND). HAND berasal dari respon sistem imun terhadap infeksi HIV dan ensefalopati terkait HIV. Beberapa studi mengemukakan teori bahwa infeksi virus pada makrofag dan aktivasi mikroglia pada SSP. Neuron, astrosit, dan oligodendrosit tidak terpengaruh oleh infeksi virus. Kaskade dari kemokin dan sitokin yang dimediasi oleh sel mikroglia yang teraktivasi menyebabkan kematian sel melalui penurunan arborisasi neuron. Proses ini dapat menyebabkan penurunan fungsi kognitif serta perubahan perilaku yang progresif pada pasien dengan HIV. ${ }^{5}$

Gejala dari HAND sendiri sangat bervariasi dari yang secara klinis tidak bermanifestasi sampai dementia berat. $^{6}$ Secara umum HAND dibagi menjadi HIV associated dementia (HAD), gejala yang lebih ringan disebut dengan minor neurocognitive disorder (MND), dan pada kasus asimptomatik disebut dengan asymptomatic neurocognitive impairement (ANI). Pada beberapa laporan kasus didapatkan pasien dengan gejala HAD ketika mereka bahkan belum memenuhi kriteria dari AIDS. Hal ini membuat memasukan gejala HAD pada kriteria diagnosis AIDS sangatlah penting. ${ }^{2}$ Klasifikasi HAND dapat dilihat pada tabel berikut: 
Tabel 1. Klasifikasi HAND ${ }^{7}$

\begin{tabular}{|c|c|c|}
\hline $\begin{array}{c}\text { Tipe HIV-associated neurocognitive } \\
\text { disorder (HAND) }\end{array}$ & Prevalensi & Kriteria diagnosis \\
\hline \multirow[t]{2}{*}{$\begin{array}{l}\text { Asymptomatic Neurocognitive } \\
\text { Impairment (ANI) }\end{array}$} & $30 \%$ & $\begin{array}{l}\text { 1. Gangguan neurokognitif pada } 2 \text { atau } \\
\text { lebih domain }\end{array}$ \\
\hline & & $\begin{array}{l}\text { 2. Tidak mempengaruhi aktifitas sehari } \\
\text { hari }\end{array}$ \\
\hline \multirow[t]{2}{*}{ Mild Neurocognitive Disorder (MND) } & $20-30 \%$ & $\begin{array}{l}\text { 1. Gangguan neurokognitif pada } 2 \text { atau } \\
\text { lebih domain }\end{array}$ \\
\hline & & $\begin{array}{l}\text { 2. Terjadi gangguan dalam kegiatan } \\
\text { sehari hari yang ringan sampai } \\
\text { sedang }\end{array}$ \\
\hline \multirow[t]{2}{*}{ HIV-Associated Dementia (HAD) } & $2-8 \%$ & $\begin{array}{l}\text { 1. Gangguan neurokognitif yang jelas } \\
\text { pada } 2 \text { atau lebih domain }\end{array}$ \\
\hline & & $\begin{array}{l}\text { 2. Gangguan pada kegiatan sehari-hari } \\
\text { yang nampak jelas }\end{array}$ \\
\hline
\end{tabular}

Diagnosis HAND dapat ditentukan dengan menilai adanya gangguan pada setidaknya lima bidang fungsi neurokognitif (fungsi eksekutif, memori episodik, kecepatan proses informasi, keterampilan motorik, atensi/memori kerja, bahasa, dan persepsi sensorik). Idealnya, domain-domain ini dievaluasi menggunakan modalitas pemeriksaan neurokognitif berbasis kinerja dan diinterpretasikan menggunakan data normatif yang sesuai demografis, jika sumberdaya terbatas dan tidak memungkinkan dapat digunakan penilaian menggunakan kuesioner Mini-Mental Status Examination (MMSE) atau Montreal Cognitive Assessment (MoCA) dan Skala Demensia HIV. Skala Demensia HIV merupakan alat yang spesifik dan valid yang dapat diulang secara serial untuk menilai tren dari gejala dan progresifitas gangguan kognitif. Gangguan neurokognitif tidak dapat dikategorikan sebagai HAND jika terkait dengan kondisi komorbiditas lain seperti psikosis dan penggunaan zat atau delirium. Diagnosis HAND sering bertumpu pada penentuan ada atau tidaknya penurunan dalam fungsi seharihari, sehingga sangat penting untuk mempertimbangkan kemungkinan faktor-faktor lain yang terlibat dalam menilai gangguan fungsional. Penilaian fungsi sehari-hari bergantung pada laporan diri yang dapat dinilai menggunakan kuesioner skala Activities of Daily
Living (ADL) dan Instrumental Activities of Daily Living (IADL). ${ }^{5,8}$

Pada pasien ini ditemukan keluhan mudah lupa sejak dua tahun lalu dimana pasien kesulitan untuk mengingat tempat meletakkan barang dan nama orang. Pasien masih dapat melakukan aktivitas sehari-hari secara mandiri tanpa memerlukan bantuan walaupun keluhan lupa terkadang mengganggu aktivitasnya. Pemeriksaan neurobehavior didapatkan adanya gangguan kognitif dimana terdapat gangguan memori terutama new learning ability, memori tunda, dan asosiasi berpasangan, serta gangguan visuospasial dan eksekutif. Hasil penilaian ADL dan IADL mandiri. Dari hasil tersebut pasien dapat dikategorikan dalam HAND tipe Asymptomatic Neurocognitive Impairment (ANI). 


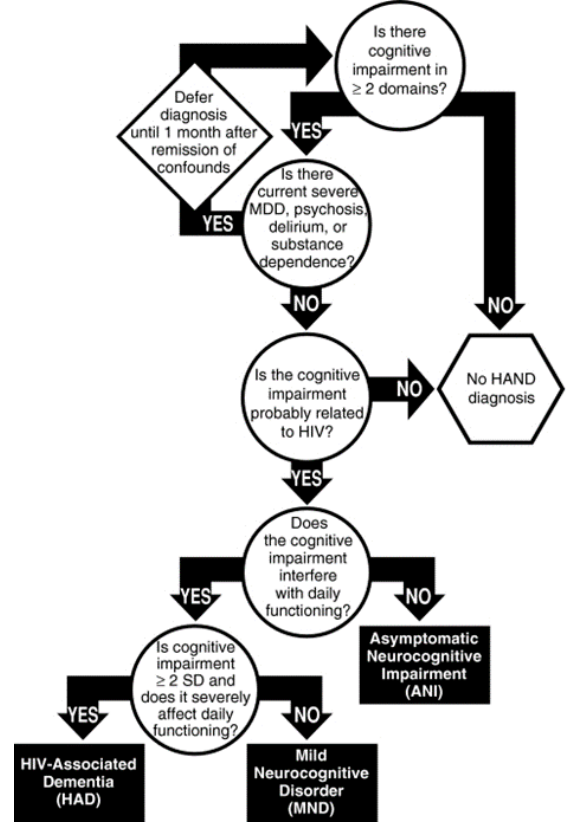

Gambar 8. Algoritma penegakan diagnosis HAND $^{8}$

Studi oleh Melrose dkk. yang menyelidiki integritas sirkuit frontostriatal yang bertanggung jawab atas fungsi eksekutif, menemukan aktivitas yang rendah pada area korteks prefrontal (PFC) ventral dan dorsolateral kiri. Ditemukan juga hipoaktivitas kaudatus kiri, yaitu berkurangnya konektivitas antara kaudatus kiri dan korteks prefrontal ventral dan dorsolateral pada penderita HIV dibandingkan orang sehat. Pada kelompok penderita HIV juga ditemukan penurunan konektivitas antara kaudatus kiri dan globus palidus. Disfungsi ganglia basalis dan korteks prefrontal ini menjelaskan gangguan fungsi eksekutif dan semantik pada penderita HIV. ${ }^{9}$

Sistem imunitas pada penderita HIV terutama limfosit $T$ yang berperan dalam sistem imun spesifik, memiliki peran penting pada progresifitas infeksi HIV. Salah satu jenis limfosit $T$ adalah sel CD4 yang merupakan target dari HIV. Kadar CD4 diketahui berhubungan dengan derajat kerusakan jaringan otak. Studi neuroimaging pada penderita HIV menunjukkan adanya pengurangan volume secara signifikan pada area substansia alba bagian frontal, lebih jelas pada ganglia basalis terutama putamen. ${ }^{10}$ Penurunan volume otak pada area kortikal dan subkortikal dapat terjadi pada penderita HIV asimtomatik dan penderita yang stabil dengan terapi ARV. Suatu studi kohort melaporkan adanya atrofi kortikal progresif berhubungan dengan kadar CD4+ nadir pada pasien HIV yang stabil dengan terapi ARV11. Pada pasien ini telah dilakukan pemeriksaan penunjang CT Scan kepala dengan kontras dengan hasil dalam batas normal. Disarankan untuk dilakukan pemeriksaan lanjutan berupa MRI kepala dengan kontras untuk dapat mengevaluasi adanya atrofi serebral difus serta perubahan white matter subkortikal atau periventrikular, walaupun gambaran ini tidak patognomonik untuk HAD. ${ }^{2,5}$

Gangguan kognitif sering ditemukan pada individu seropositif yang memiliki kadar sel CD4 dibawah $200 \mathrm{sel} / \mu \mathrm{l}$ sehingga hal ini merupakan salah satu faktor risiko HAND pada pasien dengan HIV. ${ }^{5}$ Studi oleh Widyastuti dkk. tahun 2012 pada pasien HIV di RSUP Sanglah Denpasar menunjukkan faktor risiko gangguan kognitif pada penderita HIV antara lain angka CD4 nadir rendah, CD4 current rendah, tingkat pendidikan rendah ( $<9$ tahun) dan lama diagnosis HIV lebih dari satu tahun. ${ }^{12}$ Studi lanjutan oleh Sukarini dkk. tahun 2015 pada pasien HIV di RSUP Sanglah Denpasar dan beberapa pusat kesehatan di Bali menunjukkan hubungan terjadinya gangguan kognitif pada pasien HIV pre-ARV dengan kadar CD4 rendah sembilan kali lebih besar dibandingkan pasien dengan kadar CD4 diatas $200 \mathrm{sel} / \mu \mathrm{l}$ secara signifikan13. Hal ini sesuai dengan kasus dimana pasien memiliki kadar CD4 nadir $16 \mathrm{sel} / \mu \mathrm{l}$ dan pasien telah terdiagnosis HIV sejak tiga tahun lalu.

Pasien mendapat terapi ARV dengan regimen tenofovir, lamivudine, dan efavirenz. Evaluasi ulang kadar CD4 menunjukkan peningkatan kadar CD4 menjadi $209 \mathrm{sel} / \mu \mathrm{l}$. Studi oleh Zhuang dkk. menunjukkan pemberian terapi kombinasi ARV dalam 12 minggu menunjukkan peningkatkan performa fungsi kognitif dan fungsional pada pasien tanpa terapi ARV sebelumnya dengan fungsi imunitas yang masih baik. ${ }^{14}$ Inisiasi pemberian terapi ARV dini merupakan usaha pencegahan terjadinya gangguan neurokognitif yang disebabkan oleh infeksi HIV. ${ }^{15}$

ARV sering dikaitkan dengan berbagai efek samping pada sistem saraf pusat dan perifer. Frekuensi dan derajat efek samping neuropsikiatrik sangat bervariasi. Di negara berkembang, dimana nucleoside reverse transcriptase inhibitor (NRTI) stavudine 
merupakan ARV yang umum diresepkan, neuropati perifer merupakan komplikasi penting dimana gejala klinisnya sering sulit dibedakan dari neuropati perifer terkait HIV. Neurotoksisitas yang diinduksi oleh NRTI disebabkan oleh penghambatan polimerase DNA mitokondria. Mekanisme ini juga bertanggung jawab untuk miopati mitokondria dan asidosis laktat yang terjadi pada terapi zidovudine. NRTI terutama zidovudine dan abacavir juga dapat menyebabkan manifestasi gejala susunan saraf pusat seperti mania dan psikosis. Obat golongan non-nucleoside reverse transcriptase inhibitor (NNRTI) efavirenz merupakan ARV yang paling sering dikaitkan dengan toksisitas SSP. ${ }^{16}$ Sekitar $40 \%$ pasien dengan terapi evafirenz dilaporkan mengalami efek samping berupa dizziness, insomnia, mimpi buruk, mood yang fluktuatif, jarang menyebabkan manifestasi neuropsikiatrik. ${ }^{16}$

Riwayat epilepsi diketahui memiliki peran dalam memperberat terjadinya gangguan kognitif. Mekanisme yang terjadi baik pada epilepsi dan gangguan kognitif diperkirakan akibat dari pola pensinyalan otak abnormal yang menghasilkan hipereksitabilitas dan perubahan fungsi sinaptik. Perubahan morfologis dan fungsional otak setelah kondisi status epileptikus atau kejang berulang menghasilkan perubahan dalam sirkuit saraf yang secara langsung mempengaruhi kemampuan struktur yang terkena untuk memproses informasi secara normal. Perubahan seperti dalam sirkuit saraf dapat mengubah rate coding, dimana informasi disampaikan melalui frekuensi hantaran neuron tunggal, serta temporal coding, dimana aliran informasi dicapai melalui interaksi temporal dari hantaran beberapa neuron. Kesalahan dalam rate coding dan temporal coding dapat ditemukan pada kondisi epilepsi kronis. ${ }^{19}$

\section{Daftar pustaka}

1. DPPK RI. Statistik kasus HIV/AIDS di Indonesia. 2017 [diunduh Juni 2018]. Tersedia dari: Ditjen PP \& PL Kemenkes RI.

2. Daroff RB, Jankovic J, Mazziotta JC, Pomeroy SL. Bradley's neurology in clinical practice. 2016. New edition / ed. Philadelphia: Saunders.

3. Moore DJ, Letendre SL, Morris S, Umlauf
A, Deutsch R, Smith DM, dkk.

depresi, depersonalisasi, delusi paranoid, confusion, dan ide bunuh diri. Efek samping ini umumnya diamati pada minggu pertama terapi. Diketahui terdapat hubungan antara kadar plasma efavirenz tinggi terhadap kejadian efek samping pada SSP. ${ }^{17}$ Predisposisi genetik juga kemungkinan berperan terhadap hal ini. Beberapa variasi pada sistem enzim CYP2B6 berperan dalam eliminasi efavirenz. Efek samping SSP evafirenz dapat dikurangi dengan lorazepam atau haloperidol, tetapi jika gejala masih tetap muncul setelah pengaturan ulang dosis efavirenz sampai lebih dari enam minggu, dipertimbangkan untuk mengganti regimen efavirenz. ${ }^{18}$ Golongan inhibitor HIV integrase, inhibitor reseptor $\mathrm{C}-\mathrm{C}$ chemokine tipe 5 (CCR5) dan fusion inhibitor

\section{Simpulan}

Komplikasi infeksi HIV pada sistem saraf pusat dapat berupa HIV-associated neurocognitive disorder (HAND). Kadar CD4 diketahui berhubungan dengan derajat kerusakan jaringan otak dan kadar CD4 nadir rendah ( $\leq 200 \mathrm{sel} / \mu \mathrm{l}$ ) merupakan salah satu faktor risiko terjadinya gangguan kognitif pada pasien dengan HIV. Inisiasi pemberian terapi ARV dini merupakan usaha pencegahan terjadinya gangguan neurokognitif yang disebabkan oleh infeksi HIV dan mencegah perburukan lebih lanjut. Pengendalian penyakit penyerta seperti epilepsi juga sangat diperlukan dalam penatalaksanaan gangguan kognitif pada pasien.

\section{Pengakuan}

Tidak ada

\section{Konflik kepentingan}

Tidak ada

Neurocognitive functioning in acute or early HIV infection. Journal of Neurovirology. 2011;17(1):50-7.

4. Kathryn A. Lindl \& David R. Marks \& Dennis L. Kolson \& Kelly L. Jordan-Sciutto. HIV-Associated Neurocognitive Disorder: Pathogenesis and Therapeutic Opportunities. J Neuroimmune Pharmacol (2010) 5:294-309 
5. Watkins CC, Treisman GJ. Cognitive impairment in patients with AIDS prevalence and severity. HIV AIDS (Auckl). 2015; 7: 35-47.

6. Aminoff MJ, Josephson SA. Aminoff's neurology and general medicine. 2014. Fifth edition. ed. Amsterdam: Academic Press.

7. Antinori A, Arendt G, Becker JT, et al. Updated research nosology for HIVassociated neurocognitive disorders. 2007. Neurology, 69, 1789-99.

8. Woods SP, Moore DJ, Weber E, Grant I. Cognitive Neuropsychology of HIVAssociated Neurocognitive Disorders. Neuropsychol Rev. 2009 Jun; 19(2): 152168.

9. Melrose RJ, Tinaz S, Castelo JMB, Courtney MG, Stern CE. Compromised frontostriatal functioning in HIV: An fMRI investigation of semantic event sequencing. Behavioural Brain Research. 2008;188(2):337-47.

10. Castelo JMB, Courtney MG, Melrose R J, Stern CE. Putamen hypertrophy in nondemented patients with human immunodeficiency virus infection and cognitive 134 impairments. Archieves of Neurology. 2007;64(9):1275-80.

11. Nowak MR, Navia B, harezlak J, Yiannoutsos C, Guttmann C, Singer E, dkk. Longitudinal progression of cortical atrophy in HIV-patients on stable treatment. Conference on Retroviruses and Opportunistic Infections. Boston: MA; 2014

12. Widyastuti K, Adnyana O, Sudewi R. 2012. Angka CD4+ nadir sebagai faktor risiko gangguan kognitif pada penderita HIV di RSUP Sanglah Denpasar. Neurona, vol 29 No. 3. Jakarta.

13. Sukarini NP, Sudewi AAR, Laksmidewi AAAP. 2017. Kadar CD4+ Sebagai Faktor Risiko Gangguan Kognitif Pada Penderita Human Immunodeficiency Virus PraAntiretroviral. Neurona, vol 34 No. 2. Jakarta.

14. Zhuang $Y$, Qiu $X$, Wang $L$, et al. Combination antiretroviral therapy improves cognitive performance and functional connectivity in treatment-naïve HIV-infected individuals. J Neurovirol. 2017 Oct;23(5):704-712.

15. Fessel WJ. Impaired neurocognition in HIV-infected patients: antecedents and treatment. AIDS 2009, 23:1731-1733.

16. Abers MS, Shandera WX, Kass JS. Neurological and psychiatric adverse effects of antiretroviral drugs. CNS Drugs. 2014 Feb;28(2):131-45.

17. Marzolini C, Telenti A, Decosterd LA, et al. Efavirenz plasma levels can predict treatment failure and central nervous system side effects in HIV-1-infected patients. AIDS 2001; 15:71-75.

18. Haas DW, Heather JR, Richard BK, et al. Pharmacogenetics of efavirenz and central nervous system side effects: an Adult AIDS Clinical Trials Group study. AIDS 2004; 18:2391-2400.

19. Holmes GL. Cognitive impairment in epilepsy: the role of network abnormalities. Epileptic Disord. 2015;17(2):101-116. 